九州大学学術情報リポジトリ

Kyushu University Institutional Repository

\title{
Effects of Fire-Retardant Resin Treatment and Redrying Temperature on Mechanical Properties of Hinoki Wood
}

JIN, Taiquan

Department of Housing Environmental Design, and Research Institute of Human Ecology, College of Human Ecology, Jeonbuk National University

KANG, Chun-Won

Department of Housing Environmental Design, and Research Institute of Human Ecology, College of Human Ecology, Jeonbuk National University

JANG, Sang-Sik

Department of Forest Products, College of Agriculture \& Life Sciences, Chungnam National University

MATSUMURA, Junj $\mathrm{i}$

Laboratory of Wood Science, Department of Forest and Forest Product Science, Faculty of Agriculture, Kyushu University

https://doi.org/10.5109/4103902

出版情報: 九州大学大学院農学研究院紀要. 65 (2)，pp.365-370，2020-09. Faculty of Agriculture， Kyushu University

バージョン :

権利関係 : 


\title{
Effects of Fire-Retardant Resin Treatment and Redrying Temperature on Mechanical Properties of Hinoki Wood
}

\author{
Taiquan JIN $^{1}$, Chun-Won KANG ${ }^{1 *}$, Sang-Sik JANG ${ }^{2}$ and Jnuji MATSUMURA ${ }^{3}$ \\ Laboratory of Wood Science, Division of Sustainable Bioresources Science, \\ Faculty of Agriculture, Kyushu University, Fukuoka 819-0395, Japan \\ (Received April 2, 2020 and accepted May 27, 2020)
}

\begin{abstract}
In this study, to determine the effects of fire-retardant treatment and redrying temperature on certain mechanical properties of hinoki wood, the MOR (modulus of rupture), MOE (modulus of elasticity) in bending and dynamic MOE in bending of control and fire-retardant chemically wood treated under redrying temperatures were estimated.

The drying time was shorter with an increase in redrying temperature, and the average drying rate of the water-treated wood was greater than that of the fire-retardant-treated wood. The drying curves of fire-retardant-treated wood were nearly parallel in the early redrying period. The dynamic and static MOE of the water-treated wood were reduced compared to the control. The MOR was increased slightly with an increase in the redrying temperature.
\end{abstract}

Key words: Hinoki wood, MOR in bending, MOE in bending, dynamic MOE in bending, Redrying temperature

\section{INTRODUCTION}

Wood has been an excellent building material for many years. However, its vulnerability to fire has limited its use in many applications. When heated, wood ignites and burns, producing toxic gas and leading to the loss of lives and property. Therefore, fire-retardant treatment of wood is required by building codes.

Recently, many studies have been carried out to reduce flammability with various fire-retardant chemicals. The fire-retardant compounds used for wood generally contain nitrogen, boron, or phosphorus. Although treatment with these chemicals effectively retards combustion, it may also reduce wood strength. This reduction in strength is related to both the fire-retardant chemicals and to the redrying temperatures used in the treatment process (Winandy 1988; Winandy et al. 2001). Chung (1999) found that impact on the bending strength of wood was different according to the fireretardant chemical. However, there is not enough information about the effects of these new fire-retardant chemicals on the mechanical properties of wood.

Fire-retardant treatments yield a wood with high moisture content. The wood must then be dried to achieve dimensional stabilization and reduce weight. However, the high temperatures may affect the mechanical properties of wood. Jin (2011) found that tempera-

Department of Housing Environmental Design, and Research Institute of Human Ecology, College of Human Ecology, Jeonbuk National University, Jeonju 54896, Korea

${ }^{2}$ Department of Forest Products, College of Agriculture \& Life Sciences, Chungnam National University, Daejeon 34134, Korea

Laboratory of Wood Science, Department of Forest and Forest Product Science, Faculty of Agriculture, Kyushu University, Fukuoka 812-8581, Japan

* Corresponding author (E-mail: kcwon@jbnu.ac.kr) (C.W. KANG tures above $150^{\circ} \mathrm{C}$ have a severe impact on mechanical properties and made the wood darken. Studies regarding evaluation of mechanical properties below $100^{\circ} \mathrm{C}$ are scarce.

Recently, a phosphate-based flame-retardant resin (Wen et al. 2014) with ammonium phosphate polymer (APP), guanyl urea phosphate (GUP), and phosphonic acid as the main components has been used industrially for fire-retardant treatment of wood. Determining the effects of new fire retardants and redrying temperatures on certain mechanical properties of wood is very important for production and use of fire-retardant wood.

The objective of this study was to determine the effects of fire-retardant treatment and redrying temperature on the mechanical properties of hinoki wood, which is frequently used in Korea as an interior material.

\section{MATERIALS AND METHODS}

\section{Specimen Preparation}

Samples of hinoki (Chamaecyparis obtusa) were cut parallel to the fiber direction into $20 \mathrm{~mm} \times 20 \mathrm{~mm} \times$ $320 \mathrm{~mm}$ (tangential $\times$ radial $\times$ longitudinal) sections and dried at $103 \pm 1^{\circ} \mathrm{C}$ until their weights were constant. The weight and size of each specimen was then measured. The samples were randomly divided into 3 treatment groups of 40 specimens each. A control group comprising 10 untreated samples was also examined.

\section{Impregnation and Redrying}

To achieve the different weight percent gains (WPG) of the fire retardant group, the samples were impregnated under two different schedules. The first was by applying a vacuum of 0.10 bar for 30 minutes before the solution into the treatment chamber, with a subsequent pressure of 15 bar for 2 hours. The second was by applying a vacuum of 0.10 bar for 30 minutes before the solution into the treatment chamber and subsequent pres- 
sure of 15 bar for 6 hours. For comparison, one group of samples was impregnated with water. After impregnation, the treated samples were stored at ambient conditions two days prior to redrying and then redried at $25^{\circ} \mathrm{C}, 60^{\circ} \mathrm{C}, 80^{\circ} \mathrm{C}$, and $100^{\circ} \mathrm{C}$ until their weights were constant. All treatments were carried out in a laboratory scale process.

\section{Measurement of dynamic modulus of elasticity}

The dynamic modulus of elasticity (dMOE) was determined by the free-free suspended beam technique, in which the pick-up accelerometer (Bruel \& $\mathrm{K}$ jær, Nærum Denmark) is fastened to the center of the specimen, and at the end, the specimen is struck lightly with an impulse hammer (Type 8203; B \& K). The impact causes the specimen to vibrate and the signal from the accelerometer is transformed by an FFT analyzer (Type 3065; B \& K) and processed using computer software delivering the estimated resonant frequency $\left(\mathrm{f}_{0}\right)$. From $\mathrm{f}_{0}$, the resonant frequency (f) is corrected to eliminate the influence of shear deflection (Kataoka and Ono, 1975). dMOE is then calculated using the following formulae:

$$
\mathrm{f}=f_{0}\left(1+\alpha h^{2} / L^{2}\right)
$$

where

$\mathrm{f}=$ resonant frequency, $\mathrm{f}_{0}=$ estimated resonant frequency, $\mathrm{h}=$ thickness, $\mathrm{L}=$ length of the specimen, $\mathrm{a}=\mathrm{a}$ constant (4.73 for the fundamental mode of vibration)

$$
\mathrm{dMOE}=48 \pi^{2} \rho l^{4} f^{2} / m^{4} h^{2}
$$

where

$\mathrm{dMOE}=$ dynamic modulus of elasticity, $\rho=$ density of the specimens, $\mathrm{h}=$ thickness, $\mathrm{m}=\mathrm{a}$ constant (4.73 for the fundamental mode of vibration)

The dMOE is computed from the density, beam shape, and resonant frequencies of the wood, according to Hearmon's transverse vibration theory (1966). The resonant frequencies of wood specimens were estimated from the transverse vibration of the wooden beam with an impact hammer. The apparatus setup consisted of an accelerometer (B\&K, City, Country), impact hammer (Type 8203; B\&K, City, Country), and an FFT (Fast Fourier Transform) analyzer (Type 3065; B \& K, City, Country). First, the specimen was struck properly with an impulse hammer. The impact causes the specimen to vibrate, and the FFT analyzer transforms the signal from the accelerometer. Then, a frequency response curve is acquired.

This test was repeated three times for each specimen and the data were averaged. From the spectral analysis, the resonant frequency of each small wooden board was estimated. From the estimated resonant frequencies, the dMOEs were calculated using Eq. 2. Here, the influence of the shear stress caused by different ratios of sample thickness to length was not considered because this study only focused on the influence of the fire-retardant treatment.

\section{Measurement of static MOR and MOE in bending}

Static three-point bending tests were performed using a universal testing machine (AGS-1000G; Shimadzu Corporation). Specimens were loaded to rupture with bending load parallel to the grain. The span (L) was $28 \mathrm{~cm}$ and the cross head was advanced at 10 $\mathrm{mm} / \mathrm{min}$ according to KSF 2208. The sMOE and MOR were calculated as follows:

$$
\mathrm{Es}=\mathrm{Pl}^{3} / 4 \mathrm{bh}^{3} \mathrm{~W}
$$

where Es $=$ sMOE, $\mathrm{P}=$ load, $\mathrm{l}=$ length of specimen, $\mathrm{b}=$ width of specimen, $\mathrm{h}=$ thickness of specimen, $\mathrm{w}=$ displacement.

$$
\sigma_{\mathrm{b}}=3 \mathrm{PL} / 2 \mathrm{bh}^{2}
$$

\begin{tabular}{|c|c|c|c|}
\hline Sample & $\begin{array}{l}\text { Impregnation } \\
\text { Method }\end{array}$ & $\begin{array}{l}\text { Redrying } \\
\text { Temperature }\end{array}$ & Code \\
\hline Non-treated & - & - & $\mathrm{C}$ \\
\hline \multirow{4}{*}{ Water-impregnated } & \multirow{4}{*}{$\begin{array}{l}\text { vacuum } 0.10 \text { bar } 30 \text { minutes } \\
\text { pressure } 15 \text { bar } 6 \text { hours }\end{array}$} & 25 & $\mathrm{~W}-25$ \\
\hline & & 60 & $\mathrm{~W}-60$ \\
\hline & & 80 & $\mathrm{~W}-80$ \\
\hline & & 100 & $\mathrm{~W}-100$ \\
\hline \multirow{4}{*}{ Fire-retardant impregnated } & \multirow{4}{*}{$\begin{array}{l}\text { vacuum } 0.10 \text { bar } 30 \text { minutes } \\
\text { pressure } 15 \text { bar } 2 \text { hours }\end{array}$} & 25 & $\mathrm{H}-25$ \\
\hline & & 60 & $\mathrm{H}-60$ \\
\hline & & 80 & $\mathrm{H}-80$ \\
\hline & & 100 & $\mathrm{H}-100$ \\
\hline \multirow{4}{*}{ Fire-retardant impregnated } & \multirow{4}{*}{$\begin{array}{l}\text { vacuum } 0.10 \text { bar } 30 \text { minutes } \\
\text { pressure } 15 \text { bar } 6 \text { hours }\end{array}$} & 25 & $\mathrm{~F}-25$ \\
\hline & & 60 & $\mathrm{~F}-60$ \\
\hline & & 80 & $\mathrm{~F}-80$ \\
\hline & & 100 & $\mathrm{~F}-100$ \\
\hline
\end{tabular}

Table 1. Treatment type and code for each group 
where $\sigma_{\mathrm{b}}=$ bending stress, $\mathrm{P}=$ maximum load, $\mathrm{L}=$ length of span, $\mathrm{b}=$ width of specimen, $\mathrm{h}=$ thickness of specimen.

\section{RESULTS AND DISCUSSION}

\section{Drying rate}

The initial and final MCs (moisture contents) and drying rate for each drying charge are given in Table 2 . Drying curves, which are graphical representations of the $\mathrm{MC}$ of kiln charge over drying time, for each drying charge are illustrated in Fig. 1.

The initial MC was caused by water absorption during impregnation because the samples were oven dried before treatment. And the different initial MC each other because the difference amount of penetration dur-

Table 2. Initial and final moisture content (MC), drying time, and drying rates for each drying charge

\begin{tabular}{cccccc}
\hline $\begin{array}{c}\text { Redrying } \\
\text { temperature }\end{array}$ & Treatment & $\begin{array}{c}\text { Initial MC } \\
(\%)\end{array}$ & $\begin{array}{c}\text { Finial MC } \\
(\%)\end{array}$ & $\begin{array}{c}\text { Drying Time } \\
(\mathrm{h})\end{array}$ & $\begin{array}{c}\text { Drying rate } \\
(\% / \mathrm{hr})\end{array}$ \\
\hline $25^{\circ} \mathrm{C}$ & $\mathrm{W}$ & 167.12 & 8.88 & 336 & 0.47 \\
& $\mathrm{H}$ & 53.57 & 9.12 & 336 & 0.13 \\
& $\mathrm{~F}$ & 88.02 & 10.83 & 336 & 0.23 \\
\hline $60^{\circ} \mathrm{C}$ & $\mathrm{W}$ & 167.91 & 7.83 & 26 & 6.16 \\
& $\mathrm{H}$ & 37.89 & 7.60 & 18 & 1.68 \\
& $\mathrm{~F}$ & 82.97 & 7.84 & 28 & 2.68 \\
\hline $80^{\circ} \mathrm{C}$ & $\mathrm{W}$ & 166.93 & 7.36 & 24 & 6.65 \\
& $\mathrm{H}$ & 44.58 & 6.93 & 16 & 2.35 \\
& $\mathrm{~F}$ & 75.41 & 7.17 & 20 & 3.41 \\
\hline $100^{\circ} \mathrm{C}$ & $\mathrm{W}$ & 198.71 & 7.99 & 12 & 15.89 \\
& $\mathrm{H}$ & 50.83 & 5.45 & 10 & 4.54 \\
& $\mathrm{~F}$ & 92.76 & 5.96 & 16 & 5.42 \\
\hline
\end{tabular}

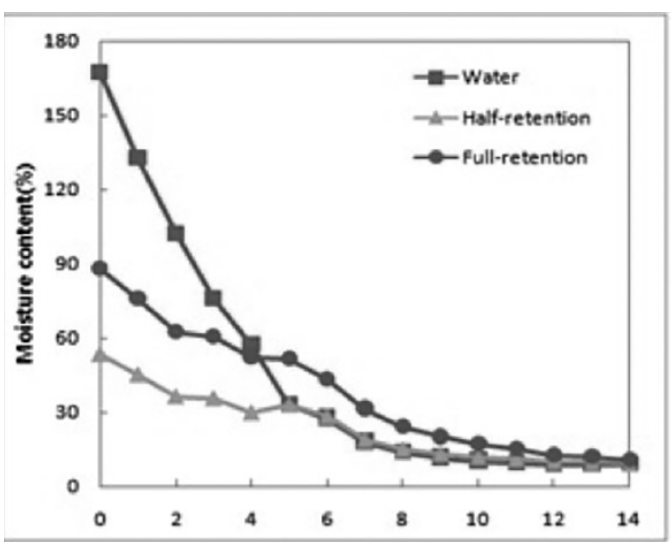

(a)

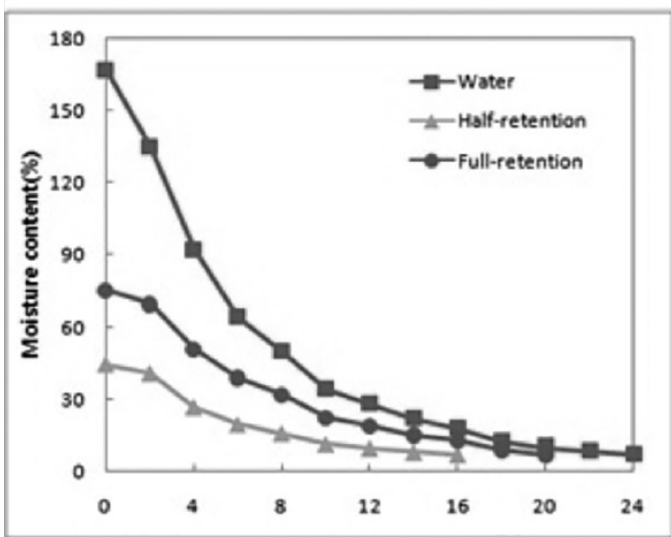

(c)

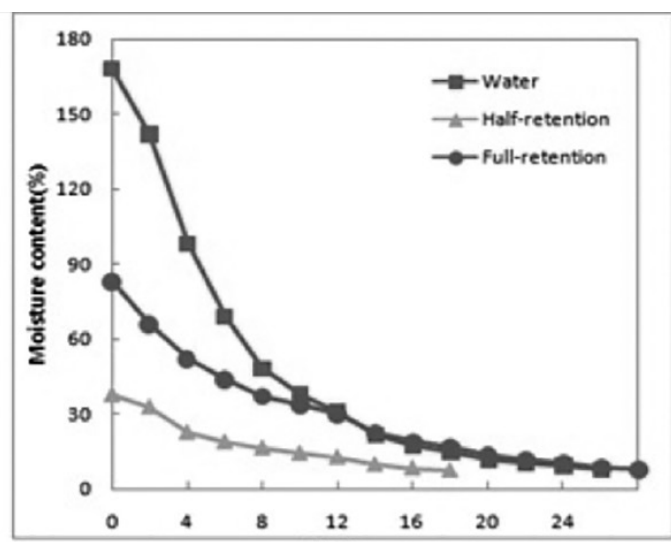

(b)

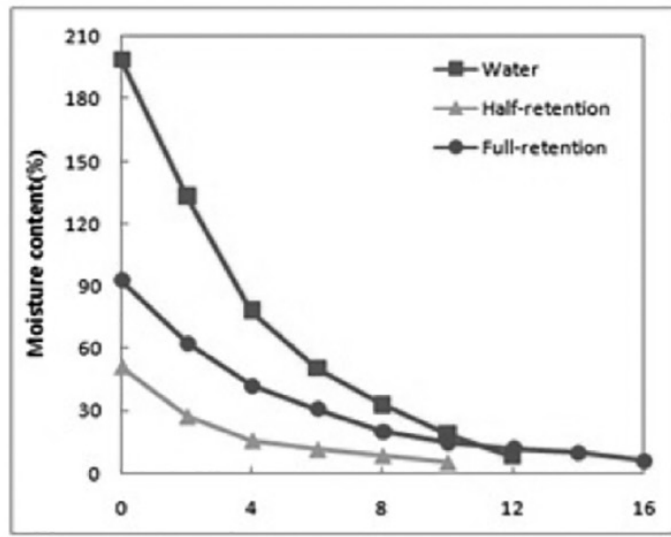

(d)

Fig. 1. Drying curve for each treatment at $25^{\circ} \mathrm{C}(\mathrm{a}), 60^{\circ} \mathrm{C}(\mathrm{b}), 80^{\circ} \mathrm{C}(\mathrm{c})$ and $100^{\circ} \mathrm{C}(\mathrm{d})$. 
ing impregnation. It was shown that the viscosity of the solution has opposite effects on the penetration.

The drying time was shorter with increases in the redrying temperature, and the average drying rate for water treatment was greater compared to the fireretardant treatment at the same redrying temperature. Both cases of water treatment or fire-retardant treatment, the MC decreased sharply from the initial value to $30 \%$ and then became slowly, as shown in Figure 1. Despite the differences in fire-retardant retention and redrying temperature, the drying curves of fire-retardant treatment of wood were very similar during the early redrying periods. It is believed that the fire-retardant solution was not coupled with cell structure inside the wood.

\section{Bending strength}

The bending strength and density data are presented in Table 3 and the influence of redrying temperature and fire retardant upon selected mechanical strengths of fire-retardant treatment of hinoki is presented in Figure 2.

According to the results, the dynamic and static MOE of water treatment were reduced and the MOR was somewhat increased compared to controls. However, Figure 2 shows that the bending strengths of watertreated wood did not significantly differ with increase in redrying temperature. This shows that water treatment somewhat affected the bending strength and the effects of redrying temperature are negligible.

Density of specimens changed more through fireretardant treatment. The MOR was enhanced and the dynamic and static MOE were reduced compared to the controls (Table 3). The bending strengths, which increased with the redrying temperature, are shown Figure 2. It is shown that the redrying temperature has a positive impact on the bending strength of fire-retardant-treated wood. However, it is difficult to determine if the fire-retardant treatment affects the bending strength, as the density was changed more by the fireretardant treatment. To better understand how fireretardant affects the bending strength of wood, we analyzed the specific dynamics, static modulus, and specific strength of all specimens. As shown in Table 3, we found that the specific dynamics, static modulus, and specific strength of the fire-retardant-treated specimens were lower than those of the controls and water-treated samples. Additionally, with larger increases in WPG, the specific dynamics, static modulus, and specific strength had larger decreases. This confirms that fire-retardant treatment reduces the bending strength of wood. Other factors may contribute to changes in other mechanical properties.

\section{Dynamic MOE in bending}

Norimoto (1982) found that materials with higher $\mathrm{dMOE} /$ density or sMOE/density are expected to lead to good sounding boards for pianos. The dMOE/density and sMOE/density decreased after fire-retardant treatment. Therefore, it is demonstrated that a low dMOE/ density and MOE/density of fire-retardant-treated wood can result in lower impact sounds when used as flooring in buildings.

Phosphorus-based compounds are some of the best-known fire-retardant treatments for wood. However, a significant issue with these compounds is the reduced strength of the treated wood products. Moreover, as previously reported by Winandy and Morrell (1998), those compounds have more noticeable negative effects on the viscoelastic properties than on the elastic properties of treated wood, similar to more acidic fire retardants. They noted that the physical and mechanical properties of wood are a complex function of cellular and polymeric structure and chemistry. They observed that changes in the chemical composition of wood directly correspond to a loss of strength. Moreover, Wang et al. (2005) reported that a decrease in bending strength can be attributed to fire-retardant

Table 3. Average mechanical properties of the specimens

\begin{tabular}{|c|c|c|c|c|c|c|c|}
\hline No. & Density & $\mathrm{dMOE}$ & MOR & sMOE & $\begin{array}{l}\text { Specific static } \\
\text { modulus }\end{array}$ & $\begin{array}{l}\text { Specific } \\
\text { strength }\end{array}$ & $\begin{array}{l}\text { Specific dynamic } \\
\text { modulus }\end{array}$ \\
\hline $\mathrm{C}$ & 0.45 & 12544.20 & 86.30 & 10772.20 & 27299.35 & 209.31 & 25760.93 \\
\hline $\mathrm{W}-25$ & 0.43 & 10989.33 & 93.07 & 10005.43 & 24695.27 & 216.80 & 23530.16 \\
\hline $\mathrm{W}-60$ & 0.43 & 11253.26 & 104.36 & 9871.63 & 22784.53 & 241.02 & 24932.14 \\
\hline $\mathrm{W}-80$ & 0.43 & 11345.52 & 98.83 & 10043.03 & 23121.65 & 228.57 & 25153.64 \\
\hline $\mathrm{W}-100$ & 0.41 & 11347.13 & 104.53 & 9997.36 & 24239.57 & 253.93 & 26267.21 \\
\hline $\mathrm{H}-25$ & 0.48 & 10979.09 & 85.41 & 9410.76 & 19531.91 & 177.65 & 20995.84 \\
\hline $\mathrm{H}-60$ & 0.55 & 11387.05 & 99.56 & 9927.80 & 18168.86 & 181.79 & 20592.95 \\
\hline $\mathrm{H}-80$ & 0.56 & 14229.69 & 108.07 & 9790.64 & 17925.60 & 196.81 & 24166.96 \\
\hline $\mathrm{H}-100$ & 0.51 & 13097.55 & 109.72 & 10470.61 & 20701.38 & 217.40 & 24578.68 \\
\hline $\mathrm{F}-25$ & 0.53 & 10580.90 & 75.42 & 9128.97 & 17163.32 & 142.11 & 18124.16 \\
\hline $\mathrm{F}-60$ & 0.58 & 11452.63 & 93.23 & 9814.14 & 17067.84 & 162.06 & 19795.04 \\
\hline $\mathrm{F}-80$ & 0.56 & 11294.92 & 96.44 & 9618.76 & 17121.51 & 171.39 & 19604.57 \\
\hline F-100 & 0.54 & 12539.99 & 107.83 & 9682.60 & 18032.89 & 201.26 & 21743.73 \\
\hline
\end{tabular}


treatment, which results in a chemical component change in treated wood, especially in the hemicellulose content after drying. After treatment, the percentage of hemicelluloses decreases compared with untreated specimens. Conversely, the lignin residue increases for phosphoric acid-treated specimens that are kiln-dried after treatment. The drying of phosphoric acid-treated specimens causes some changes in wood components. The strength loss in wood might be closely related to degradation of the branched units of hemicelluloses. Advanced strength loss that occurs later is related to further degradation of the residual hemicelluloses' main chain and the initial degradation of cellulose and lignin when wood undergoes drying post-impregnation.

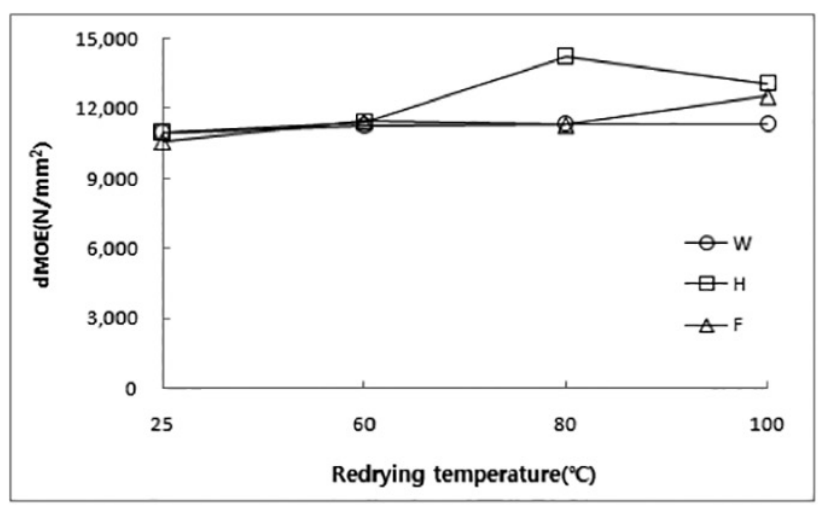

(a)

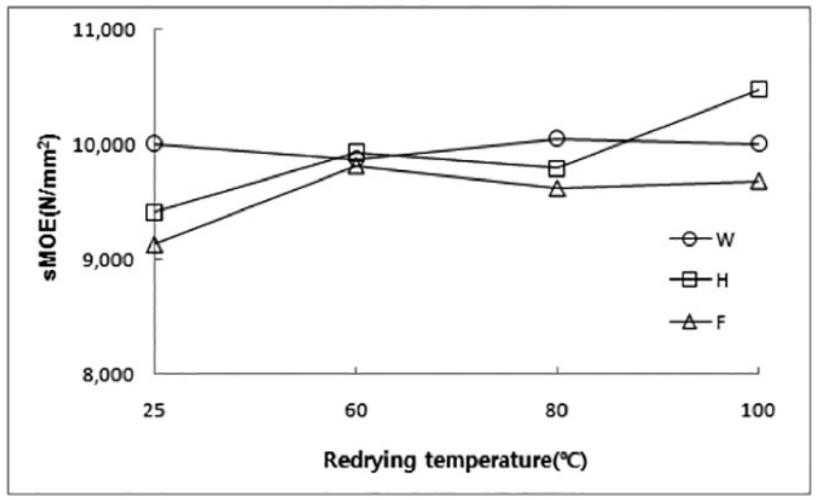

(b)

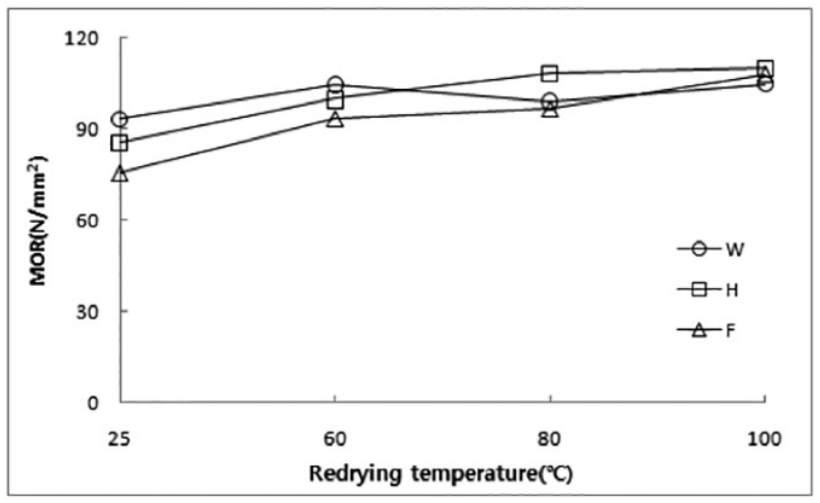

(c)

Fig. 2. Changes in mechanical values in bending according to redrying temperature.

(a) dynamic modulus of elasticity, (b) static modulus of elasticity, (c) modulus of rupture

\section{CONCLUSIONS}

To determine the effects of a phosphate-based fire retardant and redrying on the bending strength of wood, we impregnated hinoki wood with a fire retardant, redried it at $25^{\circ} \mathrm{C}, 60^{\circ} \mathrm{C}, 80^{\circ} \mathrm{C}$ and $100^{\circ} \mathrm{C}$, and measured the bending strength.

1. The drying time was shorter with an increase in redrying temperature and the average drying rate of water-treated wood was greater than that of the fireretardant-treated wood. The drying curves of fireretardant treatment of wood were very similar in the early redrying period.

2. The dynamic and static MOE of water treatment were reduced compared to the controls. The MOR was somewhat increased but was not significantly different even with an increase in redrying temperature.

3. The redrying temperature had a positive impact on the bending strength of fire-retardant-treated wood. The bending strength increased with increase in redrying temperature.

4. It is shown that fire-retardant-impregnated wood could be used as flooring in buildings because the impact sound ability, dMOE/density, and sMOE/density decreased with treatment.

\section{AUTHOR CONTRIBUTIONS}

T. Jin designed the study, performed the experiments and wrote the paper. C. W. Kang, S. S. Jang and J. Matsumura provided important comment. All authors assisted in editing of the manuscript and approved the final version.

\section{ACKNOWLEDGMENTS}

This study was carried out with the support of Basic Research Project (Project No. NRF2019R1I1A3A02059471) provided by National Research Foundation of Korea), and "Research Base Construction Fund Support Program" funded by Jeonbuk National University in 2019.

\section{REFERENCES}

Chung D-J, Jo J-S, Yun K-E, Kim J-J, Kim G-H. 1999. Effect of fire-retardant treatment and redrying on the mechanical properties of radiata pine. J Korean Wood sci and Tech 27(1): 37 $-49$

Hearmon R-F-S. 1966. Theory of vibration testing of wood. Forest Product Journal. 16(8):29-40

Jin T-Q, Kang C-W, Lee N-H, Kang H-Y, 2011. Changes in the Color and Physical Properties of Wood by High Temperature Heat Treatment. J. Fac. Agr. Kyushu Univ. 56(1):129-137

Kataoka A, Ono T. 1975. The relations of experimental factors to the vibration and the measuring value of dynamic mechanical properties of wood J. Wood Res. Soc. Japan 21(10):543-550

KSF2208 (1995) Testing wood and wood-based materials (in Korean). Korean Standard Association, Seoul, Korea, p 106

Lebow S-T, Winandy J-E. 1999. Effect of fire-retardant treatment on plywood $\mathrm{pH}$ and the relationship of $\mathrm{pH}$ to strength properties. Wood Science and Technology 33:285-298 
LeVan S-L, Ross R-J, Winandy J-E. 1990. Effects of fire retardant chemicals on bending properties of wood at elevated temperatures. Res. Pap. FPL-RP-498. Madison, WI: U.S. Department of Agriculture, Forest Service, Forest Products Laboratory. $24 \mathrm{p}$

Li C-Y, Kang C-W, Jang S-S, Kang H-Y, 2017. Relation between the dynamic modulus of elasticity and the static modulus of elasticity, the odulus of rupture of mandarin peel-sawdust composite board. J Wood Science 60:367-375

Norimoto M. 1982 . Structure and wood properties of wood used for musical instruments. J. Wood Res. Soc. Japan 28(7):407413

Patricia K-L, Winandy J-E. 1999. Verification of a KineticsBased Model for Long-term Effects of Fire Retardants on Bending Strength at Elevated Temperatures. Wood and Fiber Science, 31(1): 49-61

Sweet M-S, Winandy J-E. 1999. Influence of Degree of Polymerization of Cellulose and Hemicellulose on Strength Loss in Fire-Retardant-Treated Southern Pine. Holzforschung 53 (3): 311-317
Wang Q, Wang W, Winandy J-E. 2005. Effects of a new GUP-B fire retardant on mechanical properties of Korean pine when exposed to elevated temperature. Forest products journal $\mathbf{5 5}(12): 214-220$

Wen M-Y, Kang C-W, Park H-J, 2014. Impregnation and mechanical properties of three softwoods treated with a new fire retardant chemical. $J$ Wood Science 60:367-375

Winandy J-E. 1997. Effects of Fire Retardant Retention, Borate Buffers, and Redrying Temperature After Treatment on Thermal-Induced Degradation. Forest products journal 47(6):79-86

Winandy J-E, LeVan S-L, Schaffer E-L, Lee P-W. 1988. Effect of Fire-Retardant Treatment and Redrying on the Mechanical Properties of Douglas-Fir and Aspen Plywood. Res. Pap. FPLRP-485. Madlson, WI: U.S. Department of Agriculture, Forest Service, Forest Products Laboratory. 20p

Winandy J-E, Patricia K-L. 2001. Modeling Strength Loss in Wood by Chemical Composition. Part 1. An Individual Component Model for Southern Pine. Wood and Fiber Science, 33(2): 239-254 